\title{
PENGGEROMBOLAN TWEET BADAN NASIONAL PENANGGULANGAN BENCANA INDONESIA PERIODE AGUSTUS 2018-FEBRUARI 2019 MENGGUNAKAN TEXT MINING*
}

\author{
Windyana Pusparani ${ }^{1}$, Agus M Soleh ${ }^{2 \ddagger}$, and Akbar Rizki ${ }^{3}$ \\ ${ }^{1}$ Department of Statistics, IPB University, Indonesia, windyana_puspa@apps.ipb.ac.id \\ ${ }^{2}$ Department of Statistics, IPB University, Indonesia, agusms@apps.ipb.ac.id \\ ${ }^{3}$ Department of Statistics, IPB University, Indonesia, akbar.ritzki@gmail.com \\ $\ddagger$ corresponding author
}

Indonesian Journal of Statistics and Its Applications (eISSN:2599-0802)

Vol 4 No 4 (2020), 590 - 603

Copyright (c) 2020 Windyana Pusparani, Agus M Soleh, and Akbar Rizki. This is an open-access article distributed under the Creative Commons Attribution License, which permits unrestricted use, distribution, and reproduction in any medium, provided the original work is properly cited.

\begin{abstract}
Twitter is a popular social media platform for communicating between its users by writing short messages in limited characters, called tweets. Extracting data information that has non-structured form and huge-sized, usually known as text mining. Badan Nasional Penanggulangan Bencana Indonesia (@BNPB_Indonesia) is the official twitter account of the government agency in the field of disaster management that uses twitter to share much information about disasters that have occurred in Indonesia. This study aims to determine the characteristics of all tweets and to group the types of tweets that they shared based on the similarity of its content. The data used in the study came from BNPB Indonesia's tweets with the period of taking tweets $6^{\text {th }}$ of August 2018 to $16^{\text {th }}$ of February 2019. The cluster result obtained by the k-Means method was 4 groups. The characteristics of the first cluster contained information about the weather conditions in Yogyakarta, the second cluster was about the source and magnitude of an earthquake, and the third group was about the occurrence of earthquakes in Lombok. However, the fourth group characteristic couldn't be specifically identified because there was no clear distinction between other tweets in its members.
\end{abstract}

Keywords: clustering analysis, disaster, k-Means, text mining.

\footnotetext{
*Received Aug 2019; Accepted Des 2020; Published online on Des 2020
} 


\section{Pendahuluan}

Hasil survei Asosiasi Penyelenggara Jasa Internet Indonesia (APJII) tahun 2017 menyatakan bahwa, pengguna internet di Indonesia diduga mencapai 143.26 juta jiwa atau $54.68 \%$ dari total penduduk Indonesia. Sebanyak $87.13 \%$ dari $54.68 \%$ ini menggunakan internet untuk mengakses media sosial. Twitter menjadi salah satu platform media sosial yang populer dalam kegiatan microblogging, yang memungkinkan antar pengguna untuk saling menuliskan tweet.

Bencana alam yang terjadi secara beruntun di Indonesia pada akhir pertengahan tahun 2018 hingga awal tahun 2019 menjadi salah satu topik perbincangan yang ramai dibicarakan oleh para pengguna twitter. Akun twitter BNPB Indonesia (@BNPB_Indonesia) merupakan akun resmi lembaga pemerintahan yang secara aktif menuliskan tweet untuk menyebarkan informasi mengenai penanganan dampak bencana yang terjadi di Indonesia. Pentingnya peran akun twitter BNPB sebagai penyampai informasi bencana membuat perlunya dilakukan penelitian untuk mengelompokan isi tweet dari akun ini. Hal ini dapat digunakan sebagai kontrol apakah akun twitter BNPB telah menjalankan perannya dengan baik.

Setiap satu tweet berbentuk teks yang dibagikan oleh sebuah akun twitter akan menghasilkan satu dokumen, yang jika dikumpulkan dan diolah dengan metode tertentu dapat menghasilkan informasi yang berguna. Text mining diartikan sebagai proses untuk mendapatkan informasi dari berbagai dokumen dalam bentuk teks yang dapat bersumber dari sebuah e-mail, makalah penelitian, hingga kabar berita (Feldman et al., 2007). (Chen et al., 2014) menerapkan text mining dengan menggunakan percakapan dalam media sosial untuk memahami masalah mahasiswa jurusan teknik dalam kehidupan perkuliahan seperti beban studi yang berat, kekurangan keterlibatan sosial dan waktu untuk beristirahat. (Slamet et al., 2016) melakukan penggerombolan data teks berupa penggerombolan ayat-ayat suci Al-Qur'an untuk mengetahui kelompok konten dan eksplorasi ilmu pengetahuan yang terdapat dalam Al-Qur'an menggunakan metode k-Means.

Penelitian ini berupaya untuk menggali informasi dari data tekstual tweet akun twitter BNPB untuk mengetahui kelompok-kelompok topik pembicaraan yang disampaikan akun tersebut menggunakan metode k-Means. Keuntungan dari penggunaan metode k-Means untuk penggerombolan teks adalah tidak memerlukan iterasi yang banyak untuk mendapatkan hasil yang baik, sehingga tepat untuk diterapkan pada data teks yang berukuran besar (Mattjik \& Sumertajaya, 2011). Karakteristik setiap kelompok topik kemudian akan diidentifikasi berdasarkan hasil visualisasi teksnya.

\section{Metodologi}

\subsection{Data}

Data penelitian yang digunakan adalah data tweet pada akun media sosial twitter milik Badan Nasional Penanggulangan Bencana (BNPB) Indonesia(@BNPB_Indonesia), baik tweet yang dibuat oleh BNPB sendiri maupun yang berasal dari meretweet tweet dari akun twitter pengguna/lembaga lain. Tweet yang terambil adalah 3000 tweet teratas sejak tanggal 6 Agustus 2018 hingga 16 Februari 2019. Data tweet didapatkan setelah mendaftarkan diri melalui twitter REST API yang merupakan sistem antarmuka dalam media sosial untuk mendapatkan data dengan format tertentu. 


\subsection{Prosedur Analisis Data}

1. Eksplorasi Data

(a) Membuat hasil eksplorasi data berupa diagram tipe tweet, kategori tweet, dan kategori bencana.

(b) Menyajikan 10 kata yang paling sering muncul dengan frekuensi kemunculannya dan hasil visualisasi data tekstual berupa word cloud.

2. Pra proses data

(a) Pra proses tahap 1: Mengubah huruf kapital menjadi nonkapital (lowercase), memisahkan kalimat teks ke dalam individu kata dan frasa, menghapus tanda baca, URL, mentions ("RT"), username, angka, dan hashtag.

(b) Pra proses tahap 2: Membuat daftar stopwords berdasarkan pengamatan pada seluruh teks yang dimiliki dan menggabungkannya dengan stopwords bahasa Indonesia dari penelitian Tala (2003), dan stopwords bahasa Inggris dari Natural Language Toolkit. Bila stopwords ditemukan dalam dokumen, maka akan dihilangkan.

(c) Pra proses tahap 3: Mengubah teks ke bentuk dasarnya (stemming) berdasarkan algoritma confix-stripping Adriani et al. (2007) dengan menghapus awalan, imbuhan, dan akhiran dari setiap kata yang ditemukan.

3. Transformasi Data

(a) Membuat suatu corpus dokumen dari data tweet yang telah melalui seluruh tahap pra proses.

(b) Membentuk Document Term Matrix yaitu matriks berukuran $n x p$ dengan $n$ adalah banyaknya dokumen sebanyak 3000, $p$ adalah banyaknya kata sebanyak 1402, yang berisi pembobotan TF-IDF terhadap seluruh kata di seluruh tweet. Pembobotan kata TF-IDF untuk kata ke- $t$ dalam dokumen ke- $d$ adalah sebagai berikut:

$$
T f i d f_{t d}=T f_{t d} \times \log \frac{D}{d f_{d}}
$$

dalam hal ini $T f i d f_{t d}$ adalah bobot kata ke-t dalam dokumen ke-d, $T f_{t d}$ adalah frekuensi kemunculan kata ke- $t$ pada dokumen ke- $d$ dibagi banyaknya kata dalam dokumen ke- $d$, D adalah banyaknya dokumen, dan $d f_{d}$ adalah banyaknya dokumen yang mengandung kata ke-t (Salton \& Buckley, 1988).

(c) Menghitung nilai cosine similarity dari Document Term Matrix yaitu matriks berukuran $n \times n$ atau $3000 \times 3000$. Cosine similarity adalah sebuah ukuran kemiripan dokumen dengan menghitung nilai cosine dari sudut yang dibentuk oleh dua buah vektor. Misalkan $\mathbf{x}$ dan $\mathbf{y}$ adalah dua vektor pembobotan kata dengan TF-IDF, maka ukuran kemiripan ini dihitung dengan rumus,

$$
\operatorname{sim}(\mathbf{x}, \mathbf{y})=\frac{\mathbf{x}^{t} \mathbf{y}}{\|\mathbf{x}\|\|\mathbf{y}\|}
$$

bila nilai cosine similarity bernilai 0 , berarti sudut antara kedua vektor $90^{\circ}$, $\mathbf{x}$ dan $\mathbf{y}$ tidak memiliki kemiripan. Semakin dekat nilai cosine dengan 1, maka semakin kecil sudut yang dibentuk vektor $\mathbf{x}$ dan $\mathbf{y}$ dan semakin mirip kedua vektor atau dokumen tersebut. 
4. Penggerombolan Data dengan k-Means

(a) Menggunakan matriks cosine similarity sebagai data yang akan digerombolkan dengan k-Means.

(b) Menggerombolkan data dengan banyaknya gerombol k-Means yang dicobakan yaitu $k=2$ hingga $k=7$.

(c) Menentukan $(k)$ terpilih sebagai panduan penggerombolan berdasarkan hasil perhitungan nilai koefisien silhouette tertinggi.

(d) Mengidentifikasi karakteristik hasil gerombol awal dengan melihat visualisasi word cloud anggota masing-masing gerombol dan melakukan overfitting bila karakteristik gerombol yang dihasilkan terlihat masih dapat dipisahkan menjadi gerombol lainnya.

\section{Hasil dan Pembahasan}

\subsection{Eksplorasi Data}

Gambar 1 menyatakan proporsi antara banyaknya tweet yang ditweet oleh akun @BNPB_Indonesia dan yang diretweet dari pengguna twitter lain. Besar proporsi ini menunjukkan bahwa tweet hasil retweet lebih banyak dibandingkan tweet yang ditulis sendiri. Sebanyak 61\% atau 1842 dari 3000 tweet yang didapatkan berasal dari tweet hasil retweet dari akun twitter lain, sedangkan 39\% atau 1158 data adalah tweet yang dituliskan sendiri.

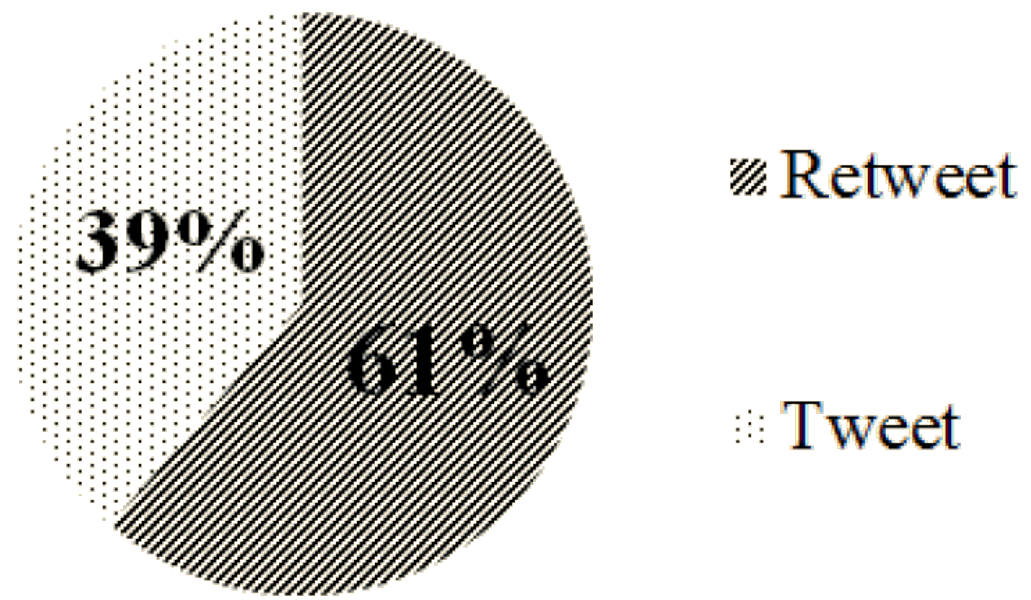

Gambar 1: Proporsi tipe tweet

Tweet hasil retweet ini didapatkan dari 246 akun berbeda, dengan lima akun paling sering diretweet adalah milik @Sutopo_PN, @infoBMKG, @PRB_BNPB, @StaklimJogja, dan @hkb_26april. Presentasi frekuensi retweet total dari lima akun tersebut sebesar $39 \%$ dan proporsi masing-masing disediakan dalam Gambar 2. Akun yang tweetnya paling sering diretweet adalah akun @Sutopo_PN, milik Sutopo Purwo Nugroho yang menjabat Kepala Pusat Data Informasi dan Humas BNPB Indonesia. Akun urutan 
kedua yaitu akun @infoBMKG, milik Badan Meteorologi, Klimatologi, dan Geofisika yang menuliskan informasi mengenai cuaca, iklim, maupun peringatan dini bencana. Akun ketiga adalah akun @PRB_BNPB, milik Direktorat Pengurangan Risiko Bencana BNPB. Akun keempat yaitu @StaklimJogja, milik Stasiun Klimatologi Mlati Yogyakarta yang menyebarkan informasi mengenai prakiraan cuaca di Yogyakarta. Akun kelima adalah @hkb_26april, akun milik panitia peringatan Hari Kesiapsiagaan Bencana yang dibentuk oleh Direktorat Kesiapsiagaan BNPB Indonesia.
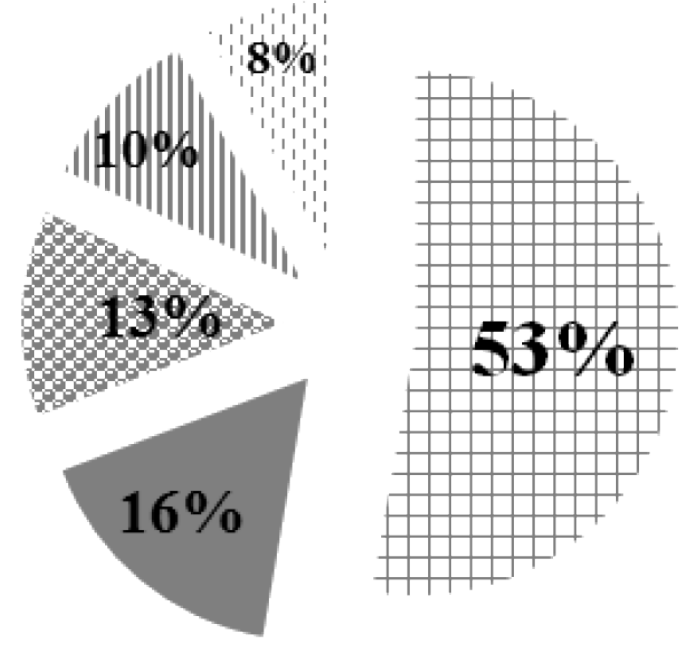

\section{+ Sutopo_PN \\ infoBMKG \\ 㩆PRB_BNPB}

IIII StaklimJogja

hkb_26april

Gambar 2: Proporsi akun yang diretweet

Gambar 3 menyatakan proporsi kategori tweet yaitu bencana dan nonbencana dengan tweet bencana lebih banyak terdapat dalam data dibandingkan tweet mengenai nonbencana. Sebanyak 66\% atau 1975 tweet membicarakan bencana, sedangkan sisanya sebesar 34\% atau 1025 tweet mengenai nonbencana. Hal ini memperlihatkan bahwa akun @BNPB_Indonesia tidak hanya menuliskan tweet atau meretweet hal yang berkaitan dengan bencana saja, namun juga hal selain bencana.

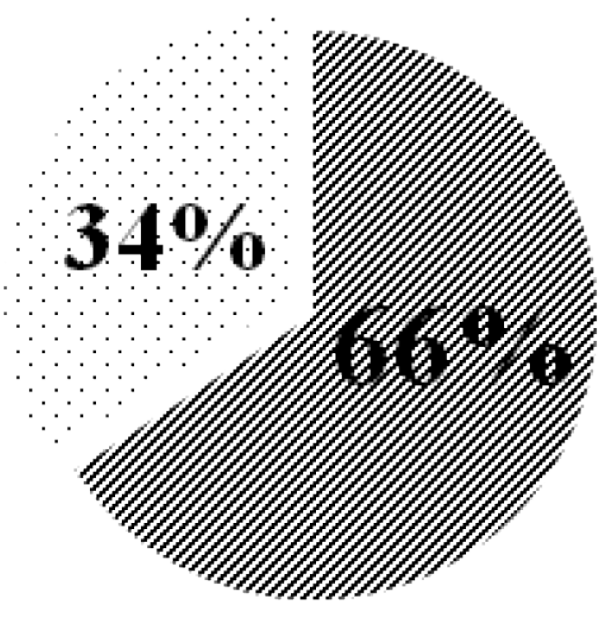

\section{\% Bencana}

\section{$\therefore$ Nonbencana}

Gambar 3: Proporsi kategori tweet 
Terdapat 18 kategori bencana menurut BNPB Indonesia yang kemudian disesuaikan dengan seluruh tweet yang dimiliki sehingga menghasilkan 13 kategori. Gambar 4 menyajikan frekuensi masing-masing kategori bencana, terlihat bahwa bencana yang paling sering disebut adalah gempa bumi sebanyak 1012 kali. Menurut publikasi infografis kejadian bencana yang diterbitkan di laman website BNPB, sepanjang Agustus 2018 hingga Februari 2019 gempa bumi telah terjadi sebanyak 20 kali kejadian yang tercatat pertama kali terjadi pada 5 Agustus 2018 berkekuatan 6.4 SR di Lombok. Gempa bumi menjadi hal paling sering dibahas karena bencana yang menelan ribuan korban jiwa ini berturut-turut mengguncang pulau-pulau lainnya di Indonesia seperti Palu dan Donggala, Bali, dan Nusa Tenggara Timur.

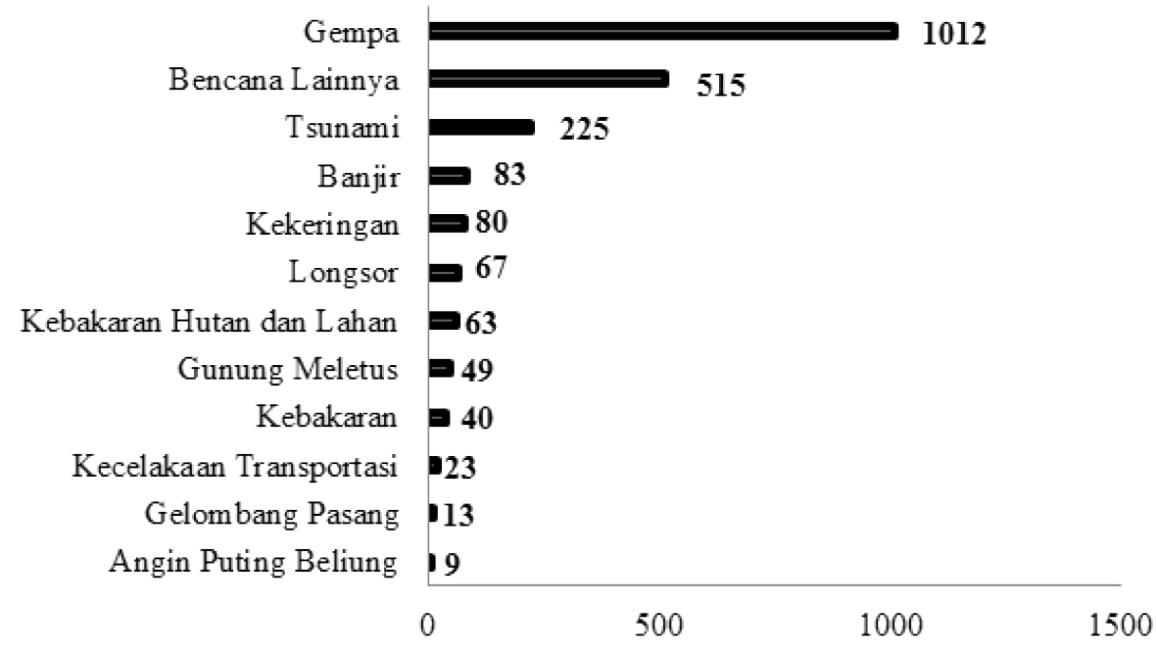

Gambar 4: Grafik kategori bencana

Terdapat sepuluh kata dengan frekuensi kemunculan terbanyak dalam seluruh tweet yang berhubungan dengan bencana dengan rincian seperti Gambar 5. Hal ini sudah sesuai dengan peran akun twitter @BNPB_Indonesia yang bertugas menyebarkan informasi mengenai bencana yang terjadi di Indonesia. Kata "gempa" sebagai kata terbanyak pertama yang ditemukan menandai banyaknya peristiwa bencana gempa bumi yang terjadi selama periode pengambilan tweet dalam penelitian ini.

Frekuensi kemunculan seluruh kata dalam keseluruhan tweet kemudian disajikan dalam word cloud seperti disajikan pada Gambar 6. Kata dengan ukuran terbesar dapat dikatakan adalah kata yang menjadi topik pembicaraan dalam seluruh tweet. Hasil visualisasi pada Gambar 6 telah sejalan dengan diagram batang pada Gambar 5, bahwa 10 kata terbanyak yang muncul terlihat jelas pada Gambar 6 .

Tabel 1 menyajikan ilustrasi perubahan tweet awal menjadi tweet yang telah melalui seluruh tahap praproses. Hasil pra proses tahapan pertama adalah seluruh tweet telah menggunakan huruf nonkapital dan seluruh tanda baca telah dihilangkan. Penghapusan link Uniform Resource Locator (URL), mention ("RT"), username akun, angka, dan hashtag (\#) yang tidak diikutsertakan dalam dianalisis. Hasil pra proses tahapan kedua adalah seluruh dokumen yang stopwordsnya telah dihilangkan berdasarkan daftar stopwords. Contoh penghapusan stopwords pada ilustrasi Tabel 1 adalah penghilangan kata "dini", "di", "tanggal", "februari", "pukul", dan "wib" dalam tweet pertama. Penghapusan kata "pgr", "info", "sr", "lok", "ls", "bt", "kedlmn", dan "km" pada tweet kedua. Penghilangan kata "dalam" dan "letnan" dari tweet ketiga. Hasil pra proses 


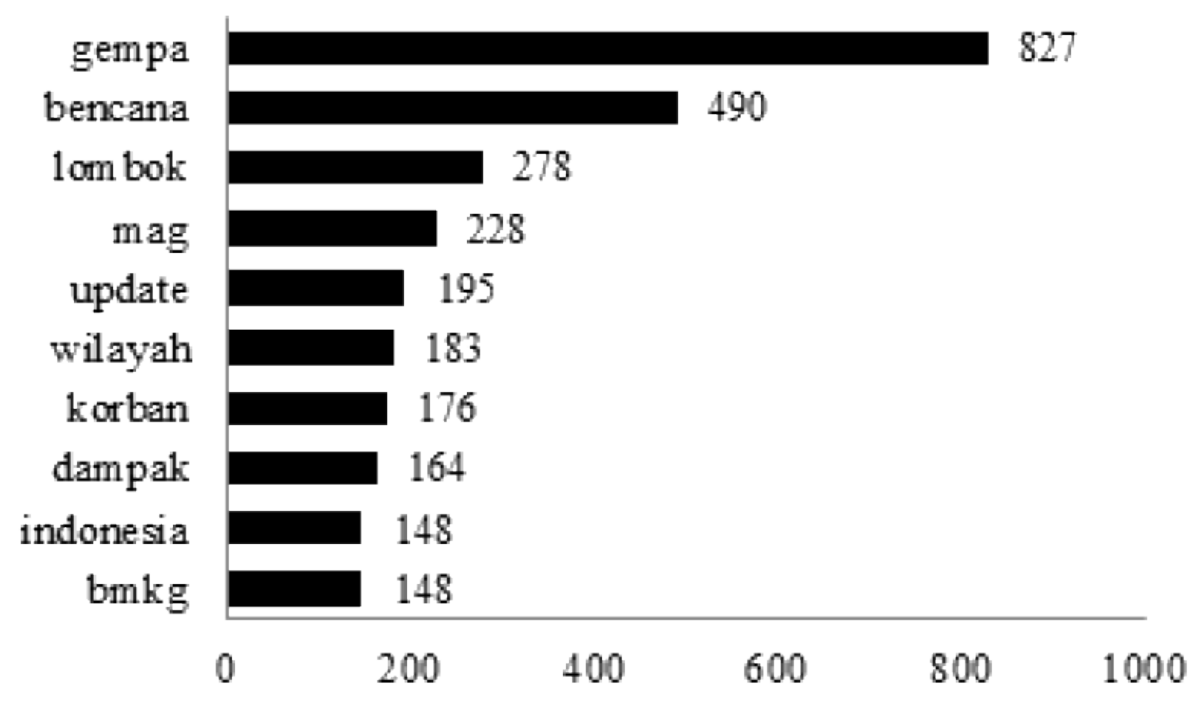

Gambar 5: Kata dengan frekuensi kemunculan terbanyak

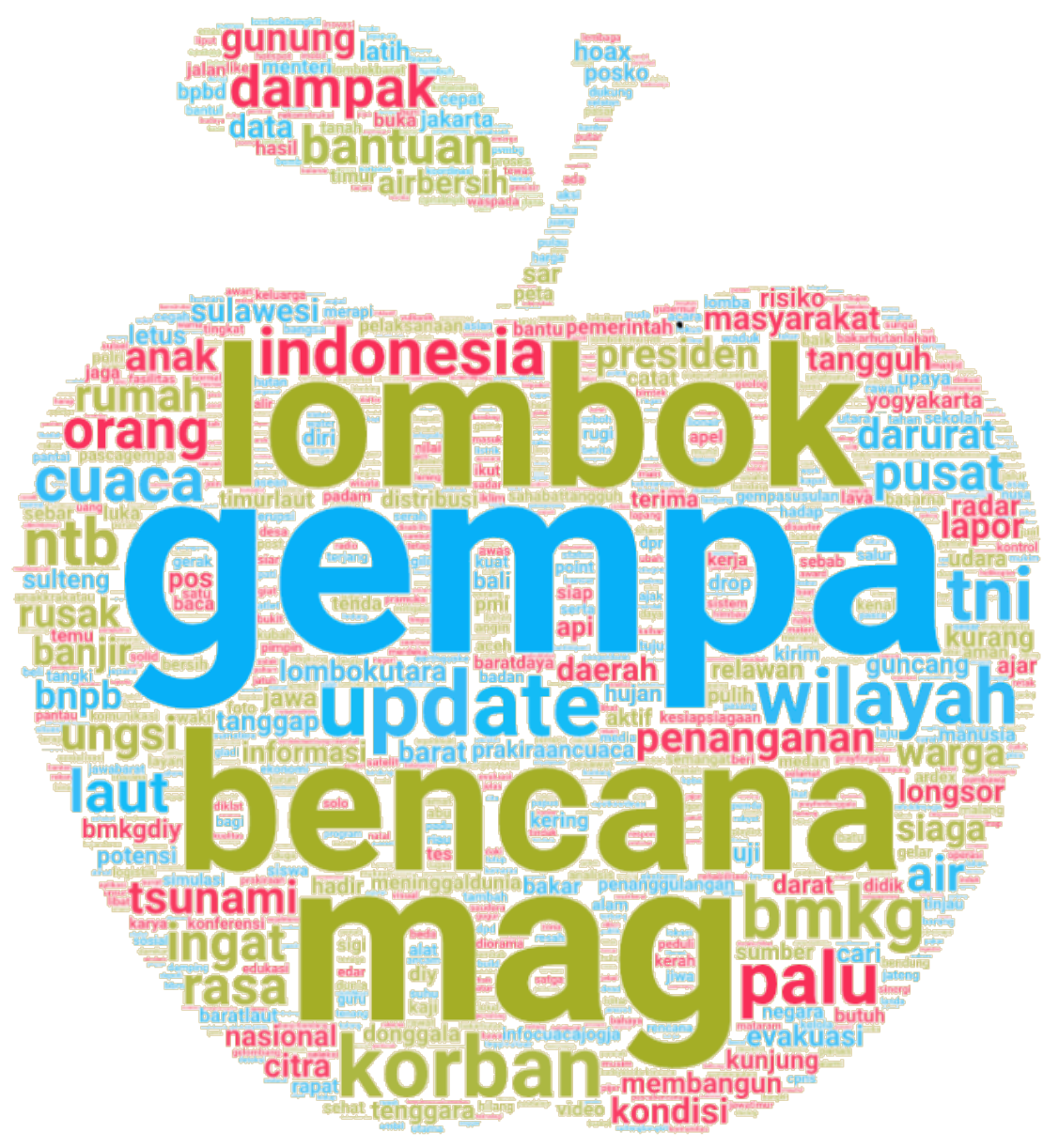

Gambar 6: Word cloud seluruh tweet 
tahapan terakhir adalah seluruh dokumen yang hanya memiliki kata dasar saja. Misalkan terdapat kata "peringatan", "mengingatkan", dan "diperingati" diubah ke kata dasarnya yaitu "ingat", sehingga kata-kata tersebut menjadi satu makna dan selanjutnya dapat memudahkan dalam analisis. Tabel 1 memperlihatkan pengubahan kata "peringatan" menjadi "ingat" pada tweet pertama dan kata "pendukung" menjadi "dukung" pada tweet ketiga.

Tabel 1: Ilustrasi perubahan tweet awal menjadi tweet yang telah melalui tahap praproses

\begin{tabular}{|c|c|c|}
\hline Tweet ke- & Tweet Awal & Setelah Pra Proses \\
\hline 1 & $\begin{array}{l}\text { RT @StaklimJogja: Update Peringatan } \\
\text { Dini Cuaca Wilayah DI. Yogyakarta } \\
\text { Tanggal } 16 \text { Februari } 2019 \text { pukul } \\
\text { \#Infolo WIB } \\
\text { \#InfocaJogja \#BMKGDIY }\end{array}$ & $\begin{array}{l}\text { update ingat cuaca wilayah } \\
\text { yogyakarta infocuacajogja } \\
\text { bmkgdiy }\end{array}$ \\
\hline 2 & $\begin{array}{l}\text { PGR } 3 \text { Bali: Info Gempa Mag:3.2 SR, 16- } \\
\text { Feb-19 15:06:13 WIB, Lok:9.65 LS,113.97 BT } \\
\text { (160 km BaratDaya JEMBRANA-BALI), } \\
\text { Kedlmn:19 Km ::BMKG }\end{array}$ & $\begin{array}{l}\text { bali gempa mag baratdaya } \\
\text { jembrana bali bmkg }\end{array}$ \\
\hline 3 & $\begin{array}{llr}\text { TNI } & \text { Komponen } & \text { Pendukung } \\
\text { dalam } & \text { Penanggulangan } & \text { Bencana. } \\
\text { JAKARTA }- \text { Kepala Badan Nasional } \\
\text { Penanggulangan Bencana Letnan } \quad \ldots \\
\text { https://t.co/iWT1FHqnsC }\end{array}$ & $\begin{array}{l}\text { tni komponen dukung } \\
\text { penanggulangan bencana } \\
\text { jakarta badan nasional } \\
\text { penanggulangan bencana }\end{array}$ \\
\hline
\end{tabular}

\subsection{Transformasi Data}

Ilustrasi pembuatan Document Term Matrix dapat dilihat pada Tabel 2 yaitu matriks berukuran $3000 x$ 1402. Setiap kata yang terdapat pada tweet akan menjadi suatu peubah atau kolom dari matriks, yang berisi nilai seluruh kata di suatu tweet tertentu yang dihitung berdasarkan pembobotan kata TF-IDF.

Tabel 2: Ilustrasi pembuatan document term matrix berdasarkan TF-IDF

\begin{tabular}{cccccc}
\hline Dokumen ke- & giat & identifikasi & sosial & $\ldots$ & runtuh \\
& 1 & 2 & 3 & $\ldots$ & 1402 \\
\hline 1 & 0.49 & 0.49 & 0.41 & $\ldots$ & 0 \\
2 & 0 & 0 & 0 & $\ldots$ & 0 \\
3 & 0 & 0 & 0 & $\ldots$ & 0 \\
$\ldots$ & $\ldots$ & $\ldots$ & $\ldots$ & $\ldots$ & $\ldots$ \\
2999 & 0 & 0 & 0 & $\ldots$ & 0 \\
3000 & 0 & 0 & 0 & $\ldots$ & 0 \\
\hline
\end{tabular}

Tabel 3 merupakan contoh tampilan cosine similarity matrix yaitu matriks yang berukuran $n x n$ atau $3000 x 3000$ dari Document Term Matrix yang berasal dari jarak kemiripan cosine antar satu dokumen dengan dokumen-dokumen lainnya. Nilai-nilai yang ada dalam matriks cosine similarity akan digunakan sebagai dasar pengelompokkan data dengan metode k-Means. 
Tabel 3: Cosine Similarity Matrix

\begin{tabular}{cccccc}
\hline & Dokumen1 & Dokumen2 & Dokumen3 & Dokumen4 & Dokumen5 \\
\hline Dokumen1 & 1 & 0 & 0 & 0.245 & 0 \\
Dokumen2 & 0 & 1 & 0 & 0 & 0 \\
Dokumen3 & 0 & 0 & 1 & 0 & 0 \\
Dokumen4 & 0.245 & 0 & 0 & 1 & 0 \\
Dokumen5 & 0 & 0 & 0 & 0 & 1 \\
\hline
\end{tabular}

\subsection{Hasil Penggerombolan}

Tabel 4 menyajikan daftar nilai koefisien silhouette untuk banyaknya gerombol sebanyak 2 hingga 7 gerombol. Terlihat bahwa nilai koefisien silhouette tertinggi yaitu sebesar 0.338 dengan banyaknya gerombol sebanyak 3 gerombol. Banyaknya gerombol ini akan dijadikan panduan banyaknya gerombol awal.

\begin{tabular}{cr} 
Tabel 4: Nilai koefisien silhouette pada $k=2$ hingga $k$ \\
\cline { 1 - 2 } Banyaknya Gerombol $(k)$ & Koefisien Silhouette \\
\hline 2 & 0.313 \\
3 & $\mathbf{0 . 3 3 8}$ \\
4 & 0.164 \\
5 & 0.174 \\
6 & 0.162 \\
7 & 0.107 \\
\hline
\end{tabular}

\subsubsection{Karakteristik Hasil 3 Gerombol}

Banyaknya anggota masing-masing gerombol pada penggerombolan tweet ke dalam 3 gerombol disajikan pada Tabel 5. Gerombol pertama banyaknya anggota paling sedikit yaitu 56 tweet. Gerombol 3 berisi anggota terbanyak yaitu 2710 tweet yang menunjukkan bahwa tidak ditemukannya kata yang dominan sebagai pembeda karakteristiknya dengan gerombol yang lain.

Tabel 5: Banyaknya anggota masing-masing gerombol

\begin{tabular}{cr}
\hline Gerombol ke- & Banyaknya Anggota \\
\hline 1 & 56 \\
2 & 234 \\
3 & 2710 \\
\hline
\end{tabular}

Gambar 7 menyajikan visualisasi anggota Gerombol 1. Terlihat bahwa data yang termasuk dalam anggota gerombol pertama adalah tweet mengenai update keadaan cuaca di Yogyakarta berdasarkan pantauan citra radar BMKG Yogyakarta. Hal ini mengindikasikan tweet hasil retweet dari akun @StaklimJogja sebagai akun peringkat keempat paling sering diretweet akun BNPB Indonesia, yang menyebarkan update 
informasi cuaca Yogyakarta kemudian membentuk sebuah gerombol yang berdiri sendiri. Contoh salah satu tweet anggota gerombol ini adalah "RT @StaklimJogja: Update Citra Radar Cuaca Wilayah DI. Yogyakarta Tanggal 17 Maret 2019 pukul 05.00 WIB \#InfoCuacaJogja \#BMKGDIY".

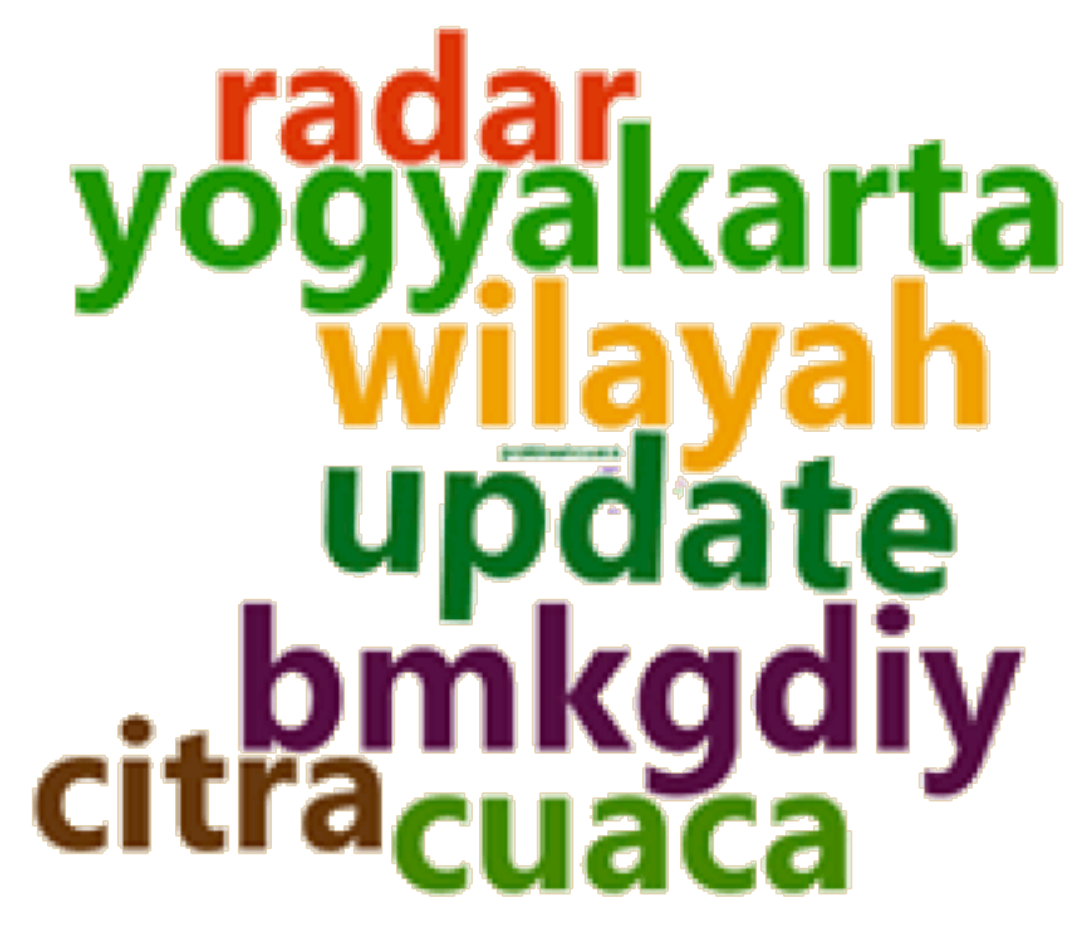

Gambar 7: Word cloud anggota Gerombol 1

Anggota gerombol kedua berdasarkan Gambar 8 adalah kumpulan tweet yang memberi informasi mengenai sumber pusat gempa bumi dan nilai besarannya. Sumber gempa bumi didefinisikan contohnya oleh kata "baratdaya", "tenggara" yang menunjukkan pusat gempa terjadi, sementara nilai besaran gempa bumi ditandai dengan kata "mag" yang berarti "magnitude". Hal ini mengindikasikan tweet hasil retweet dari akun @infoBMKG sebagai akun urutan kedua paling sering diretweet akun BNPB Indonesia yang membicarakan pusat dan besaran gempa membentuk suatu gerombol dengan salah satu tweetnya adalah "RT @infoBMKG: \#Gempa Mag:5.6, 13-Okt-18 11:34:16 WIB, Lok:1.36 LU, 125.46 BT (Pusat gempa berada di Laut 38 km Tenggara Bitung), Kedlmn:97”.

Gambar 9 menyajikan visualisasi anggota gerombol terakhir yaitu tweet yang membicarakan beragam hal dan tidak ada kecenderungannya terhadap topik tertentu. Hal ini menunjukkan bahwa penggerombolan pada Gerombol 3 belum terpisah dengan baik karena tidak ditemukan pembeda antar satu tweet dengan tweet yang ada dalam gerombolnya sehingga gerombol tidak membicarakan hal tertentu yang dapat diidentifikasi jenis kontennya. Karakteristik yang belum spesifik inilah yang menyebabkan dilakukannya overfitting menjadi 4 gerombol.

\subsubsection{Karakteristik Hasil 4 Gerombol}

Tabel 6 menyajikan banyaknya anggota hasil gerombol sebanyak 4. Terlihat bahwa banyaknya anggota gerombol pertama dan kedua tidak jauh berbeda dari penggerombolan 


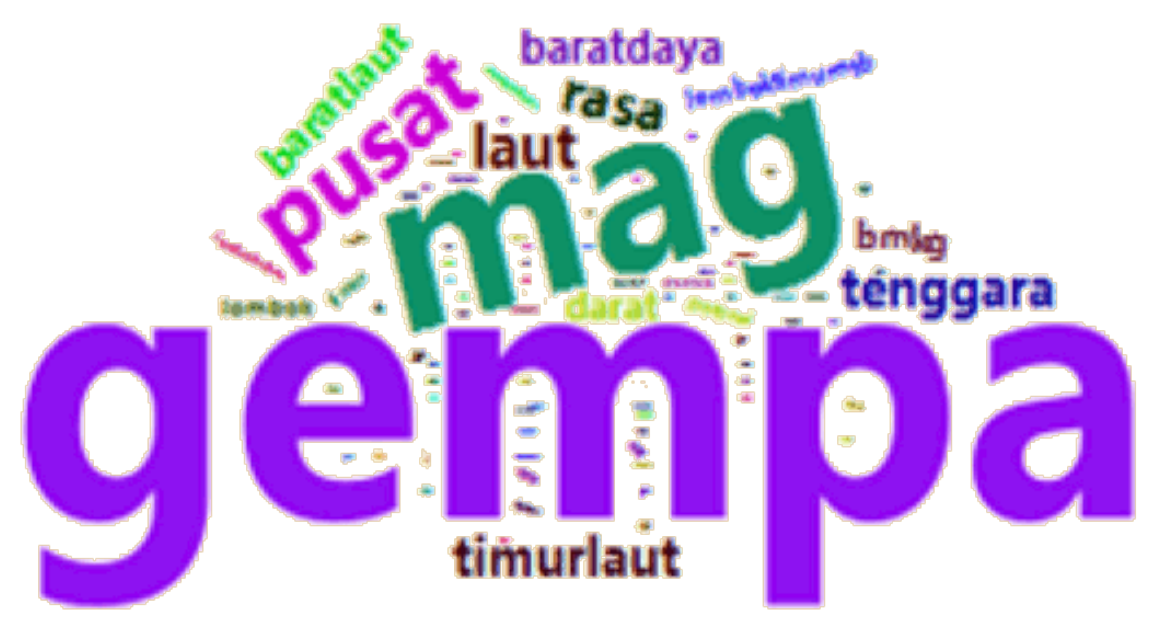

Gambar 8: Word cloud anggota Gerombol 2

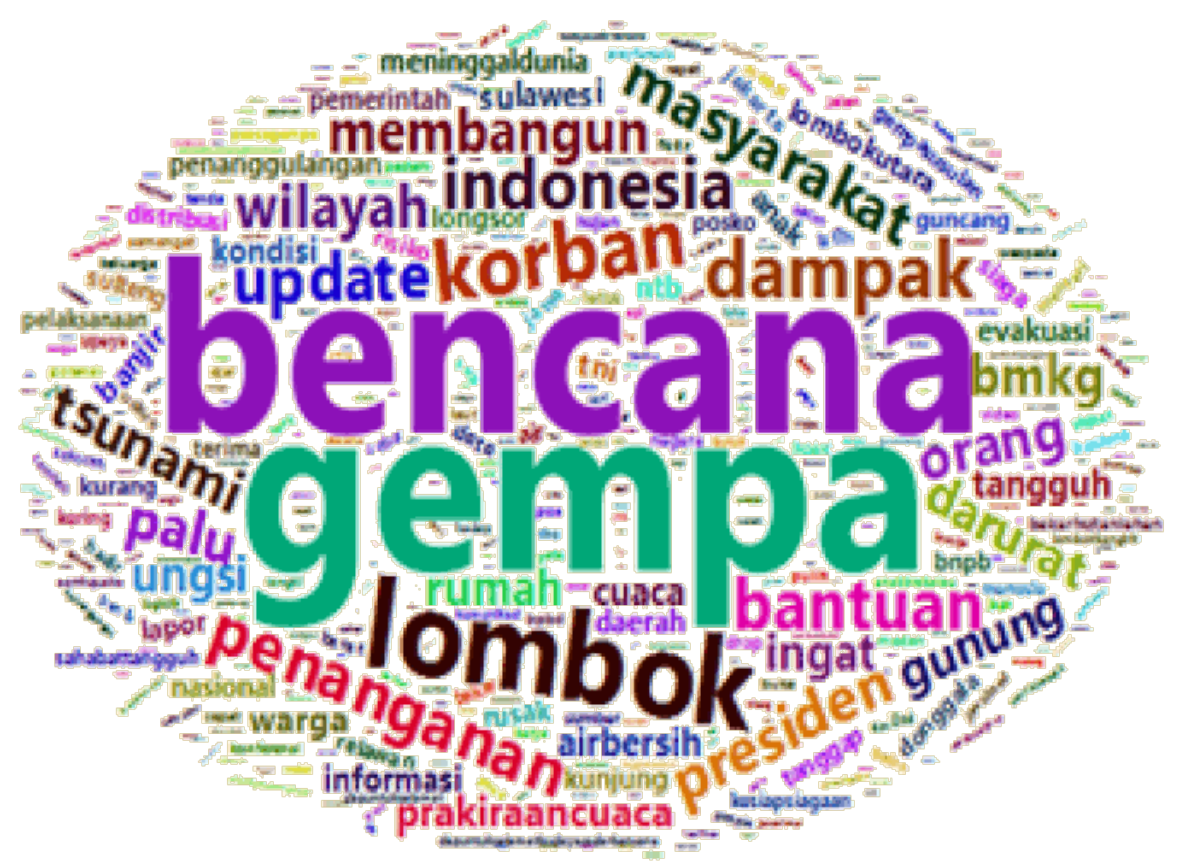

Gambar 9: Word cloud anggota Gerombol 3 
sebelumnya, namun Gerombol 3 terpisah menjadi gerombol ketiga dan keempat. Terlihat

Tabel 6: Banyaknya anggota masing-masing gerombol

\begin{tabular}{cr}
\hline Gerombol ke- & Banyaknya Anggota \\
\hline 1 & 56 \\
2 & 222 \\
3 & 496 \\
4 & 2226 \\
\hline
\end{tabular}

pada visualisasi anggota Gerombol 1 dan 2 pada Gambar 10, bahwa data yang termasuk dalam anggota gerombol pertama dan kedua sama dengan anggota gerombol pertama dan kedua pada banyaknya 3 gerombol. Hal ini menandakan kekonsistenan anggota gerombol pertama dan kedua, sehingga penggerombolan keduanya sudah baik.

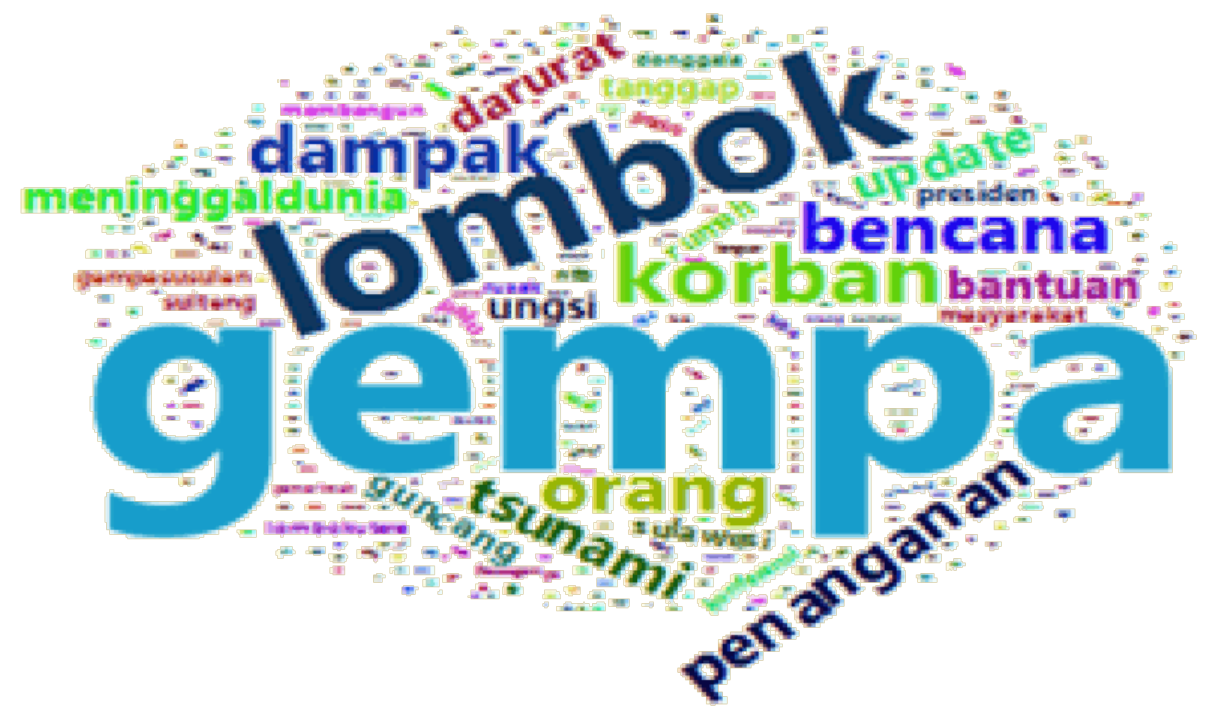

Gambar 10: Word cloud anggota Gerombol 1 (a) dan (b) Gerombol 2

Gambar 11 menyajikan visualisasi anggota Gerombol 3. Anggota gerombol ketiga adalah tweet mengenai bencana gempa bumi di Lombok pada 5 Agustus 2018 yang diwakili kata "gempa" dan "lombok" sebagai kata yang mendominasi anggota Gerombol 3. Meskipun jenis konten yang disimpulkan adalah kejadian gempa bumi di Lombok, anggota Gerombol 3 juga bercampur dengan peristiwa gempa yang diikuti tsunami setelahnya di Palu dan Donggala, Sulawesi Tengah pada 28 September 2018 yang ditunjukkan oleh kata "tsunami" dan "sulteng" pada word cloud.

Terlihat pada Gambar 12 bahwa anggota gerombol keempat adalah tweet yang membicarakan beragam hal dan tidak spesifik kecenderungannya terhadap topik tertentu. Hal ini menunjukkan bahwa penggerombolan pada gerombol 4 tidak terpisah dengan baik karena tidak ditemukan pembeda antar satu tweet dengan tweet lainnya yang ada dalam gerombolnya sehingga tidak dapat diidentifikasi jenis kontennya.

Hasil penggerombolan k-Means yang sudah dilakukan melalui proses pemilihan banyaknya gerombol berdasarkan nilai silhouette coefficient kemudian dilakukannya proses overfitting menunjukkan bahwa gerombol terbaik adalah gerombol sebanyak 4 . Hal ini diperkuat dengan hasil penentuan konten anggota berdasarkan karakteristiknya, terlihat bahwa gerombol pertama dan kedua pada penggerombolan ke dalam 3 maupun 


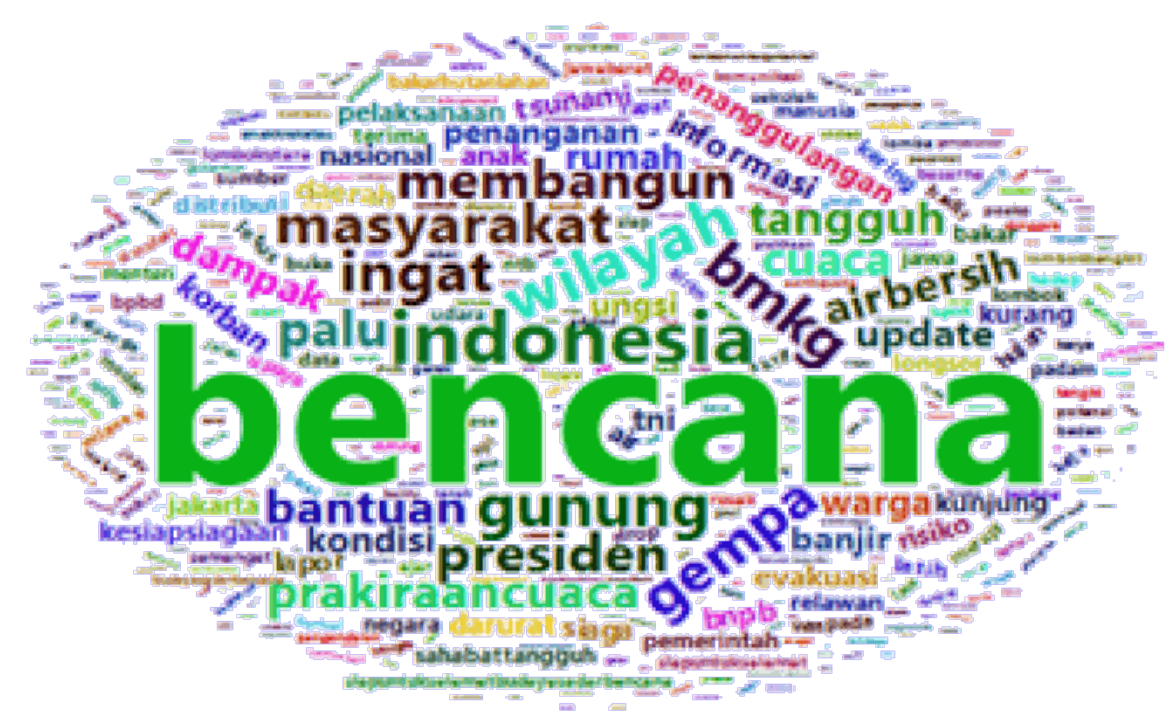

Gambar 11: Word cloud anggota Gerombol 3

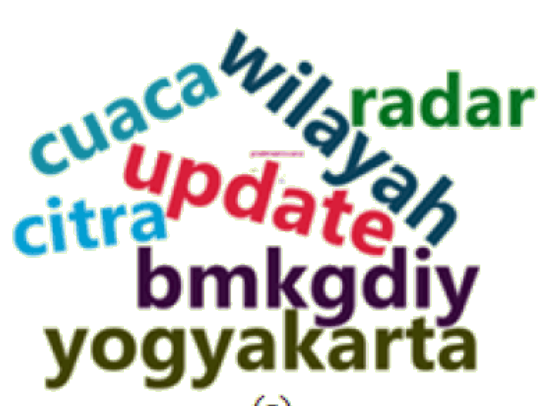

(a)

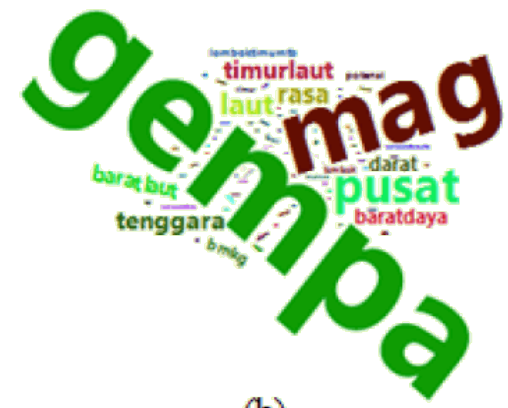

(b)

Gambar 12: Word cloud anggota Gerombol 4 
4 gerombol konsisten membicarakan mengenai gempa bumi dan keadaan cuaca Yogyakarta. Perlakuan overfitting untuk memisahkan anggota gerombol ketiga menjadi gerombol ketiga dan keempat diketahui telah mempengaruhi hasil penentuan karakteristik sebelumnya karena pembeda dari karakteristik konten telah dapat didefinisikan dengan jelas.

\section{Simpulan dan Saran}

Penggerombolan tweet pada akun twitter BNPB Indonesia (@BNPB Indonesia) menggunakan metode text mining dan analisis gerombol tak berhierarki k-Means berdasarkan kemiripan karakteristiknya menghasilkan gerombol terbaik sebanyak 4. Hal ini didasarkan pada hasil overfitting dari penentuan banyaknya gerombol menurut koefisien silhouette tertinggi. Karakteristik anggota Gerombol 1 adalah tweet mengenai update cuaca Yogyakarta melalui citra radar, Gerombol 2 tentang sumber dan besaran gempa bumi, serta Gerombol 3 tentang kejadian gempa bumi di Lombok. Namun demikian, Gerombol 4 tidak dapat diidentifikasi karakteristiknya karena tidak ditemukan pembeda yang jelas antar tweet dalam gerombolnya.

Penelitian selanjutnya pada penggerombolan tweet dapat menggunakan metode spherical k-means yang bermanfaat untuk membandingkan dan melihat metode yang memiliki hasil penggerombolan lebih baik.

\section{Daftar Pustaka}

Adriani, M., Asian, J., Nazief, B., Tahaghoghi, S. M., \& Williams, H. E. (2007). Stemming indonesian: A confix-stripping approach. ACM Transactions on Asian Language Information Processing (TALIP), 6(4): 1-33.

Chen, X., Vorvoreanu, M., \& Madhavan, K. (2014). Mining social media data for understanding students' learning experiences. IEEE Transactions on learning technologies, 7(3): 246-259.

Feldman, R., Sanger, J., et al. (2007). The text mining handbook: advanced approaches in analyzing unstructured data. Cambridge university press.

Mattjik, A. A. \& Sumertajaya, I. (2011). Sidik peubah ganda dengan menggunakan SAS. Bogor (ID): IPB Press.

Salton, G. \& Buckley, C. (1988). Term-weighting approaches in automatic text retrieval. Information processing \& management, 24 (5): 513-523.

Slamet, C., Rahman, A., Ramdhani, M. A., \& Darmalaksana, W. (2016). Clustering the verses of the holy qur'an using k-means algorithm. Asian Journal of Information Technology, 15(24): 5159-5162.

Tala, F. (2003). A study of stemming effects on information retrieval in Bahasa Indonesia. Amsterdam (NL): Institute for Logic, Language and Computation, Universiteit van Amsterdam. 